\title{
The Political Economy of Industrialisation in Nigeria: Is Ethnicity a Constraint?
}

\author{
Lionel Effiom ${ }^{1}$, Okonette Ekanem ${ }^{2} \&$ Charles Effiong ${ }^{1}$ \\ ${ }^{1}$ Department of Economics, University of Calabar, Calabar, Nigeria \\ ${ }^{2}$ Department of Public Administration, University of Calabar, Calabar, Nigeria \\ Correspondence: Lionel Effiom, Department of Economics, University of Calabar, Calabar, Nigeria. E-mail: \\ leoeff2002@yahoo.com
}

Received: January 13, 2020

Accepted: February 25, 2020

Online Published: January 18, 2021

doi:10.5430/rwe.v12n1p293

URL: https://doi.org/10.5430/rwe.v12n1p293

\begin{abstract}
Is Nigeria's multi-ethnic and multicultural configuration responsible for her low level of industrialisation? Is ethnic pluralism really a significant constraint to Nigeria's industrial development? What role has Nigeria's political economy played in foisting industrial underdevelopment on Nigeria? What lessons can be learnt from other industrialised but multi-ethnic countries, as Nigeria strives to industrialise? These were the questions that claimed our attention in this paper. The paper discountenances and refutes the hypothesis that ethnicity is responsible for Nigeria's lack of industrialization, but rather places the burden for Nigeria's under-industrialization at the doorsteps of vested interests, neo-colonial dependence, and the distorted, dependency worldview of the ruling class responsible for industrial policy formulation.
\end{abstract}

Keywords: ethnic pluralism, industrialization, political economy, Nigeria, vested interests

\section{JEL Classification: $\mathrm{O} 14$}

\section{Introduction}

From overwhelming evidence, it can be said that there is a silent and unofficial consensus in Western and liberal scholarship that puzzles on the social, cultural, political and economic phenomena related to Africa are approached from ethnic perspective almost exclusively. Western media also follow this approach in their reportages and analysis of conflicts in Africa. It does not matter whether it is the crises in the Congo in the 1960's, the political differences in Uganda, Kenya, Somalia, the Sudan, Liberia, Sierra Leone, the Gambia, Libya or the Cameroon. The Nigerian Civil War has made the list too, among others.

In the same way, pure economic failures across the continent in one way or the other, are also attributed to the same factor and traced to particular leader(s) from given ethnic groups, like in the case of Zimbabwe under Dr Robert Mugabe and others. Some African scholars in the same ideological persuasion, also interpret social and economic phenomena from the same perspective. In Nigeria, much of the economic vicissitudes in the past two decades, especially since the end of military rule have been attributed to the same causes or factors.

The theoretical foundation stone for this approach was laid by the modernisation school who claimed in the 1960's and 1970's that much of the issue of underdevelopment and crises in Africa centred on ethnic pluralism. The ethnic pluralism then, according to this argument, is aggravated by the inability of the emergent African states to cope well with the demand of modernisation that seeks to strip them of the robe of traditionalism, such that on the one hand, they strive to abandon their traditional ways of organizing society and are pulled towards the direction of modernization and the new systemic institutions and culture that go with it. At the same time, they are inhibited by a counter force from traditional cultural forces that war against these modernization tendencies. The outcome, according to the proponents, is system dysfunction that snatches legitimacy away from the leadership, seen to be representatives of one ethnic formation or another. In the ensuing scenario, the system becomes unstable as conflict and violent political changes take place and the economy remains in the doldrums.

Since the 1970's when the works of Kupper and Smith (1969), Melson and Wolpe (1971), Post and Vickers (1973), Hansen (1977), Apter (1965), Emerson (1960), Rostow (1960), Huntington (1968), among many others, analysis of social phenomenon in Africa based on this approach has gained currency and has been adopted widely. Melson and 
Wolpe (1971) were very confident in their analysis of Nigeria based on this framework. One may like to find out how empirically valid is this framework that always sees ethnic pluralism as the continental bogeyman that torments the African governments' economy and society, such that Nigerians themselves are not left out in the understanding of social, political and economic phenomena in their country from this perspective.

In general and especially since 2015 when the centre right political party led by a former military head of state won election at the expense of the far-right Peoples' Democratic Party (PDP), national discourses have increasingly been shifted to the ethnic factor irrespective of the fact that between the ruling party, the All Progressive Congress (APC) and the PDP, there is not much ideology that genuinely separates them as the top leadership keep on moving from one party to another, carrying followers along with them each time they are on the move.

Allegations that political appointments have been skewed in favour of the Hausa-Fulani ethnic groups in the North which also corresponds with their practice of the Islamic faith are daily made in the media. Despite government refutations, the ethnic tone in debates on the performance of public institutions and the economy continue unabated. This suggests how ubiquitous this framework is, even in casual conversation. When the agitation for secession in different parts of the country is added to the litany, the picture becomes clearer but more paradoxical.

Given all of these, together with the on-going ruthless war in the North-East of the country between self-styled Islamic militants called Boko-Haram and the national security forces, there is increasing cause to think that these destruction of security and economic infrastructure in the region and several parts of the country do negate economic development. Admittedly, capital, private or public, foreign or national, does not thrive in violent social, political and economic environment. If the capital is foreign, it will take a flight and even local capital can relocate as well in search for profit. Thus with apparent disinvestment and absence of new investment initiatives, industrialisation at best is slow and at worst, non-existent. Given claims made and conclusions reached by proponents of the ethnic pluralism approach, it is tempting to endorse the approach in analysing the industrialisation issue in the Nigerian political economy.

Several research questions underline this study. One, given the context underlined above, is ethnic pluralism a significant variable undermining Nigeria's industrial development? Second, have ethnic pluralism and ethnic conflicts in anyway hampered the state's policy response to Nigeria's slow pace of industrialisation? Third, what lessons can be learnt from other industrialised but multi-ethnic countries, as Nigeria strives to industrialise? Fourth, how have the dominant neo-colonial relations between the local wing of the Nigerian ruling class and its foreign partners impacted on industrial development policy choice and adoption (such as in the case of the Structural Adjustment program, SAP) and how have these consequential choices impacted on the pace and depth of industrialisation of the Nigerian economy? Our thesis is that Nigeria's ethnic plurality is not responsible for her low pace of industrialisation, as erroneously assumed. Rather, our findings place the burden for Nigeria's under-industrialization at the doorsteps of vested interests, which manifest in lunatic plundering of the national treasury.

The rest of the paper proceeds as follows. Following the introduction, section 2 addresses conceptual and theoretical issues. Section 3 discuses the relationship between ethnic pluralism, ethnic conflict and industrial development in Nigeria. Sections 4 and 5 review the trends and industrial development plans in Nigeria and the comparative indigenous economic strengths, respectively. In section 6 an evaluation is made of the policy responses of the Nigerian State to industrial development. Section 7 examines the adoption of the SAP and neo-colonial dependency and the consequences of this as industrial policy and development in Nigeria. The next section concludes the paper.

\section{Conceptual and Theoretical Issues}

\subsection{Tribe and Ethnic Groups}

An ethnic group refers to a people who are distinguished by their common cultural origin, including language and ancestry. In terms of political organisation and political consciousness, it is a group that is more enlightened than tribe. A tribe on the other hand is a primitive socio-economic category, knit together by common ancestry and found mostly in a fixed location. On the other hand, members of ethnic group are larger, more advanced and easily move away from their ancestral homeland. Both concepts are definite scientific categories; but as Fanon (1966) and Nnoli (1980) observe, it was colonial racism that reduced all ethnic groups in Africa to 'tribes' in order to justify their domination over them as uncivilised groups helped into civilisation as the white man's burden. According to Fanon (1966), there is first affirmed the existence of human groups having no culture; then of hierarchy of cultures and finally, the concept of cultural relativity.

It can be added that even if and when tribe and ethnic group are used derogatorily or meant to convey negativity and 
conflict, by themselves, both are natural states of existence or constitute a stage in their evolution as socio-economic categories. They do not necessarily create conflicts. Conflict is only associated with each when a situation of rivalry with similar groups arise. In that case, tribe transforms into tribalism and ethnic groups transform into ethnicity. Both states constitute a conflictual relationship of various states and intensity and may culminate into armed conflicts if not controlled.

Ethnicity is a subjective perception of who belongs to a particular group (Payne \& Nassar 2008: 249). It is evident that the resort to ethnic roots in the face of personal disappointment is associated with an important component of ethnicity, namely, identity or ethnic identity. This idea, originally expressed by Dominguez (1986) is an important factor, an ingredient that oils the wheel of ethnicity in almost all circumstances. We thus surmise, that since in the economic, political, social and cultural spheres, the fault lines of ethnicity is substantially blurred and insignificant, Nigeria's industrialization efforts could proceed along the same ethnic-neutral path. In other words, ethnicity should not be a significant variable explaining Nigeria's under industrialization.

\subsection{Industrialisation}

The concept of industrialisation is intertwined with that of economic growth, for it is the former that largely births the latter. The concept of industrialization implies the movement of an economy from a primarily agricultural orientation to a mixed or industrial/service basis with an accompanying increase in output and output per capita. In its broadest sense, industry refers to the production of goods from available raw materials, especially when that production is accomplished with machines. Industrialisation therefore is essentially the transition to an economy based on the large scale, machine-assisted production of goods by a concentrated, usually urban, population of workers.

The industrialization process is initially guaranteed when there is systemic and targeted policy measures steering resources into the productive process, so that eventually growth of output is generated through growth in productivity. Industrialization is said to be firmly rooted in an economy when there is a relative decline in the importance of the agricultural sector and its contribution to GDP vis-à-vis a contemporaneous increase in the output shares of the industrial sector to GDP. With these inverse relationships to national income comes a sustained growth of total output. Three broad outcomes are generated through the industrialization process: consumer goods are guaranteed, capital goods are produced which enables the production of more consumer goods, and lastly social overhead capital (Ekpo, 2004; Zurekas, 2001). All economies, especially developing ones seek the benefits of industrialization, for in them lies the greater benefits of economic growth and development. To this end, the industrialisation process, being a complicated phenomenon involving technical, social, human, cultural, institutional, as well as political dimensions, has been formalized in various models and theories so that economies, especially those of the capitalist persuasion can replicate and control its growth trajectory (Rostow, 1960; Romer, 1986; Romer, 1990; Schumpeter, 1942).

\subsection{Theoretical Issues}

Three broad theoretical perspectives exists in explaining the nexus between ethnicity (or more specifically ethnic diversity or ethno linguistic fractionalisation) and economic performance. The first argues that more homogeneous states have a propensity to exhibit higher growth rates than multi-ethnic and diverse states. In other words, multi-ethnic and cultural societies are a disincentive to growth (Schuly, 2005; Easterly and Levine, 1997; Alesina, et al., 1999, 2003; Rodrick, 1999). Min et al. (2010) for instance maintains that it compromises the quality of political institutions and governance; Rodrick (1999), that it frustrates the enthronement of sound economic policies; Alesina, et al.(1999), that it undermines the provision of public goods for the benefit of society. The second group maintains however that ethnic pluralism is good. By mobilising and coordinating the diverse culture, skills, abilities, and experiences of the component groups - innovation, creativity and productivity is enhanced (Collier, 2000; Alesina, Spolaore and Wacziarg, 2000). The United States of America is often cited as a model of a prosperous ethnic diverse nation. The third is the Marxist materialist theory that combines the history of the society with its economic base and the psychology of the leadership to explain development or lack of it, and the issue of culture and how groups relate and vie for advantages. We briefly review specific theories on the relationship between ethnicity diversity and economic performance.

\subsubsection{Social Identity Theory}

The social identity theory emphasizes that an evaluation of intergroup patterns of behaviour shows that individuals may confer positive utility to the welfare of members of their own group and negative utility to members of other groups (Tajfel et al., 1971). Alesina and La Ferrara (2000) extend and formalize this concept by showing that in a heterogeneous population, "individual utility from joining a group depends positively on the share of group members 
of one's own type and negatively on the share of different types"

Ethnic diversity also influences economic outcomes by the subtle strategies agents adopt. In the presence of market imperfections, individuals may pursue optimality and efficiency by preferring to transact with members of their own group. For instance Greif (1993) contends that merchants in Medieval times "formed coalitions along ethnic lines in order to monitor agents by exchanging information on their opportunistic behaviour". Such affiliations helped preserve a mechanism of reputation in the context of disproportionate information. La Ferrara (2003) however shows that strategies can also be dependent on one's ethnic identity in the presence of perfect information. Thus the existence of the impossibility in legally enforcing contracts (which increases the likelihood of self-help or self-enforcement) ensures individuals resort to cooperative strategies within the ambience of their ethnic groups. From here the individual benefits from both punishment and reward which arises from such ethnic group membership. Fearon and Laitin (1996) share these sentiments in their analysis of inter-ethnic cooperation. Situating this within the Nigerian context, one then wonders why there is a crass absence of a cointegration of skills, even within the narrow enclaves of the respective regions where the big three ethnic groups (Hausa/Fulani, Yoruba, and the Igbo) command hegemonic dominance.

Thirdly, ethnic diversity could affect the aggregate production function. Alesina Spolaore and Wacziarg (2000) show that by interpreting intermediate goods to mean individual skills within the framework of a "Dixit Stiglitz production structure", output can be increased. Thus, the implicit argument here is that ethnic diversity directly correlates with economic growth. However, to what extent can heterogeneity be tolerated, since by implication 'more heterogeneity is always better than less'? A trade-off must inevitably exist, which of course lies outside the production function. Lazear (1999 a, b) takes up this challenge and shows that though different skills arising from ethnic plurality or diversity may increase aggregate productivity, a trade-off ensues which arises from difficulty in communication between people of different languages and culture. O' Reilly Williams and Barsade (1997) support this hypothesis by empirically showing that 'more diversity leads to more conflict and less communication, but controlling for the latter it also leads to higher productivity.'

\subsubsection{Alesina and La Ferrara Theory of Ethnic Diversity}

Building on the different strands of social identity theory reviewed above, Alesina and La Ferrara (2005) develop a theory of the cost and benefits of ethnic diversity. The theory shows a potential positive relationship between ethnic diversity and economic development. In developed economies where labour input per worker is considerably huge, labour heterogeneity provokes increased output. Implications of the theory are significant. First, variety in production are the potential benefits of ethnic heterogeneity, while the cost emanates from the failure of a consensus on common public goods and public policies. Second, more ethnically diverse societies may produce more private goods with lower taxation and exhibit a tendency of producing less public goods. Third, more advanced societies may attract the benefits in production from heterogeneity in skills than developing countries.

However, earlier empirical studies on the implications of ethnic diversity on economic performance seem to indicate that the former breeds conflicts among ethnic groups for national resource control [see for instance studies by Easterly (2001), Bluedom (2001), and Alesina et al (2003)]. This exacerbates internal structural instability which manifest in rent-seeking behaviour and sabotage of state efforts at economic development. Thus, an inverse relationship exist between ethnic diversity and economic performance. Easterly (2001) for instance show that the effect of ethnic diversity or fractionalisation is dependent on the quality of institutions. His conclusions indicate that ethnic diversity dampens economic performance in countries with poor institutions. On their part, Alesina et al (2003) find a strong negative effect of ethnic diversity on growth in less democratic countries and a weak impact of same in countries with deep democratic values and credentials. Nyong's (2017) empirical study of the relationship among ethnic diversity, country size, ethnic political exclusion, quality of government institutions and economic development in a subset of advance capitalist countries found out, among other things, that ethnic diversity is not correlated with economic development in the presence of good institutions.

It must be noted that the above theoretical evaluations find resonance in Nigeria. While deep ethnic and religious cleavages characterize most aspects of our national life, defining the trajectory of our overall socio-political and economic development, the argument of this paper nonetheless remains and aligns with the Alesina and La Ferrara (2005) theory of ethnic diversity as well as Collier (2000) that ethnic diversity has a growth-enhancing impact. Nations are governed by elites, and aggregately their interests conflate, percolate and diffuse into the lower layers of the population. Thus underdevelopment occurs if these interests are not congenial to growth but only exist to serve a clannish few. In section 2.3.4 we take a closer look at the wider theoretical and practical ramifications of these interests. 


\subsubsection{The Neo-Marxist (Materialist) Theory}

All the above perspectives reviewed are from a common epistemic family, namely, or what Marxists would refer to, as bourgeois. They, admittedly, are very helpful in describing the scenario of ethnicity and group behaviour from a psychological stand point. Outside this and compared with the quality of what the Marxist perspective offers, it can be said that they are all focussing on the shadow or the effects of the phenomenon with very little to offer in terms of the substance or the causes.

It is very difficult to overlook the critical contributions of some Marxist scholars in the area of African studies, especially on the issue of ethnic relations. Barongo (1983) is one of these contributors. Among other observations, he states that the African society cannot possibly be the only one with multi-ethnic formations. "Nor is cultural heterogeneity a peculiar feature of these societies making African politics different from that of the United States of America, Canada or even the United Kingdom, all of which are equally heterogeneous societies".

Barongo's argument which is the position of the Marxist scholars in general also relies and focuses on history as a methodological tool without which such a phenomenon can hardly be understood - that two sets of countries are the same heterogeneous, cultural traits but the same heterogeneity is a problem for one and not for the other. He links the present African situation to the past, typical of the Marxist tradition and identifies history of the past and the present as a tool that is capable of resolving the puzzles at least, partially. By so doing, Barongo draws the attention of his readers to the historic phenomena of colonialism and imperialism that have affected these societies, their culture, their economic organisation and the pattern by which they interact politically.

According to this approach, there is no way we can understand, for instance, the phenomena of ethnicity and underdevelopment unless we make conscious effort to appraise the contemporary experiences and particularly appraise how the African countries are struggling to coexist with the other countries who had laid the foundations and erected the superstructure of the current global financial and economic institutions dominated by the Western capitalist powers.

It is on the basis of the above premises, especially the historic western capitalist intervention in the political, economic, social and cultural systems of these African societies that rather than enrich, impoverishes them. It is here that the materialist interpretation of history, has its imprint. Even before the analysis of Barongo, Neo-Marxist paradigms such as Dependency, World System and other approaches have been used to explain and demonstrate the predatory impact of such historical intervention of the West in the economy and resources of their preys. Leading works in this area include those of Ake (1981), Kay (1974), and Amin (1974). The works of Rodney (1972) and that of Chinweizu (1978) aptly document how imperialist intervention really destroyed the foundation of industrialisation in Africa. What the British did to the Indian textile industries is a good example too.

The systematic and systemic predatory relationships between the African countries and imperial countries facilitate the draining of African resources. The resultant scenario is scarcity of material resources in these African societies. Even simple economic theory teaches that when goods are in short supply, demand is raised to a higher level and sometimes hoarding of goods ensue. This brings about desperation among buyers in the midst of the scarcity.

It is this organised scarcity that triggers off desperation among groups and generates sometimes unbridled rivalry in political and economic spheres as effects and not causes. This point is emphasised with documented evidences by Nnoli (1980). Here the author documents how the colonial intervention in Nigeria devastated the local craft and related undertakings, substituted food crops with "cash" crops, created unprecedented unemployment and waves upon waves of unidirectional migration from the rural to urban centres, for desperate search for jobs. Here language was the strongest bond to bind immigrants from one region that tried to settle in another and the trust that one from one's ethnic background would facilitate early settlement and job placement.

This was in addition to another structural device to separate the difficult peoples for easy domination. It is similarly recorded by Nnoli (1980), that colonialism deliberately, as a matter of colonial state policy, separated linguistic groups from one another, especially in residential areas:

"For example in Northern Nigeria, it was the official British policy to separate Hausa-Fulani from the Southerners. At first, Southern and Northern migrants to Northern cities lived together in harmony. This embarrassed the official view that only characterised conflicts among African tribes. Hence, the migrants were forced to set up abode in 'sabongaris'. Initially, both the Southern and Northern migrants lived in 'Sabongaris'. Later, the Northern migrants were compelled to live in another section of the city, Tudun Wada.

This citation emphasises the exogenous forces that have acted on the coherence and harmony among the various 
peoples in African states and societies. Hardly any liberal narrative captures this historical reality. All that is seen is a romance with theoretical superficialities. In the above citation, 'Sabongari' is translated 'strangers' quarters. Hence colonialism made one linguistic group an artificial defence that colonial capitalism needed to divide and rule, as well as divide and exploit the people.

To conclude, this materialist/historical approach by Marxist scholars is founded on a conceptual tripod of analysis, namely, 'the condition of the economic base of the society, the historical experiences of that society, and the actors' perception, interpretation and response to environmental stimuli'. Barongo does not underrate the role of culture or 'the values of the people tied up with their beliefs and the dominant system of ideas in shaping the political process and in dictating particular forms of political organisation. However, he is convinced that these beliefs, values or ideas reflect fundamentally in the mode of production or the economic foundation of society as well as the relations it creates among the people and also the historical experiences of the society.

This approach clearly marks a point of departure from what exists in extant liberal literature on ethnic relations in Africa, especially, its historical evolution and how it impacts on the economy and political organisation of society. This is found compelling enough to serve as our substantive theoretical framework of analysis for this work. This is more so because the approach is integrated, encompassing past influences, structured to impact on what happens in society as the fall-out of history, the material base of the society (economy) which sets the tone and whose buoyancy or scarcity determines the intensity or otherwise of conflicts and the psychological which has to do with individual or group understanding, perception, interpretation of phenomena and quality of response to environmental stimuli and challenges.

\subsubsection{The 3-I Political Economy Model}

We situate our enquiry of the implications of Nigeria's political economy on its industrialization architecture by appealing to the 3-I political economy model (see Figure 1).

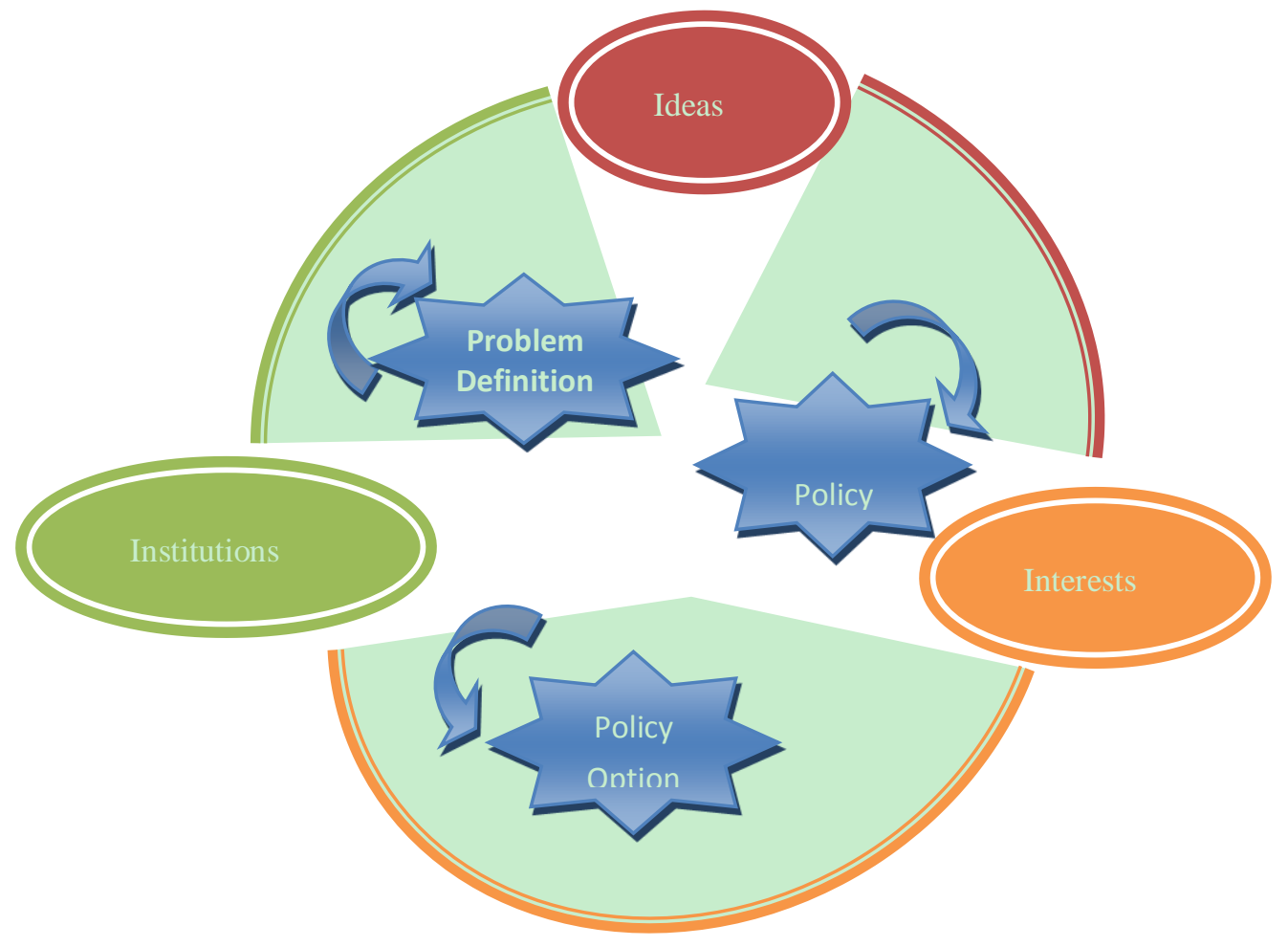

Figure 1. 3-I framework

Put succinctly, the model asserts that developments in policy and social change are determined by political actors' interest, ideas, and the set of dominant institutions (Pomey et al., 2010; Lavis et al., 2002; Hall, 1997). This dialectical tool has both retrospective and prospective merits, for it provides the analytical lens into the past and confers a 
prognosis to the inevitable future, if the same entrenched politico-economic dynamics persist. Thus, in the subsections that follow, we use these factors to provide answers to one of our research questions: What role has Nigeria's political economy played in foisting industrial underdevelopment in Nigeria? First, we show how vested interests have stagnated and compromised Nigeria's industrialisation efforts; how these interests are permanent, entrenched, inter-generational, ethnic-neutral, and cuts across party lines. Aggregately, we demonstrate that a marriage of the dominant interest, ideas, and institutions in the Nigerian society largely explain how the society defines its problems (including the urgency and primacy of such challenges), and the policy options and choices it settles for.

\subsubsection{Vested Interests}

Pomey et al. (2010) defines interest as "agendas of societal groups, elected officials, civil servants, researchers, and policy entrepreneurs". This sums up the general notion that choices and policy development are influenced by perceived and existential interests of stakeholders both within and outside of government. A power relationship exist, as it were, between the State which objectively represents the masses and the stakeholders who most often install, control and manipulate State machinery to protect their ends. Vested interest could be regarded as a group which enjoys benefits arising from a subsisting political or economic privilege. It is "the material benefits that people and groups see as directly provided to them by particular institutions or programs" (Moe, 2015). These benefits, however, do not necessarily revolve within a narrow enclave of beneficiaries; they are often spread beyond the immediate space and time.

Another definition by Moe (2015) which fits into Nigeria's political and economic narrative is that which sees vested interests as "small groups that receive substantial benefits from their programs and institutions, with costs widely diffused over the larger population". Notice that three attributes qualify the concept: vested interests are small groups relative to the general population; secondly, they extract benefits to themselves; finally, the costs accruing from their activities are borne by the wider population. Thus, in the evaluation of policy, two pertinent questions arise: who wins and who loses? Secondly, by how much do they win or lose. The latter is an enquiry into level of concentration or diffusion of either cost or benefits. The theoretical assumption of the 3-I model is that the more concentrated the benefits and cost are within groups and individuals, the more they would create coalitions in pursuit of these interests. On the contrary, those who face more diffused cost and benefits are less likely to tow the same path (Stone, 2001: Wilson, 1995).

\subsubsection{Ideas}

The second element in our analytical framework is the role of ideas, which refers to "knowledge or beliefs about what is (e.g., research knowledge), views about what ought to be (e.g., values), or combinations of the two" (Pomey et al., 2010, p. 709). Ideas can indeed sway the way in which economic agents and other societal actors specify and proffer solutions to a problem. The adoption of specific policy choices and options by State actors is mostly a reflection of the dominant and prevailing idea of the society. At that aggregative level, ideas become values, norms, attitudes, which consequently dictate the quality and sets of policy choices finally embraced. They ultimately become fossilized, structural moral codes and ideologies which even dictate the type of economic and political institutions a society adopts.

As if to controvert the significance of vested interest in the political economy of development, Keynes (1936) asserted that "sooner or later, it is ideas, not vested interests, which are dangerous for good or evil". Fasan (2017) argues that "ideas flow from intellectuals, visionary leaders and the dominant values and cultures in a society." Thus, "change only happens when ideas lead to a normative consensus and political momentum in favour of a particular cause of action". Put differently, ideas are inherent in the prevailing and dominant institutions of society. For instance, there exists a general normative consensus across ethnic and religious divides against same-sex marriage unions, so entrenched that legislations legitimising (if any) such relationships can hardly survive in Nigeria. Similarly, in the sports arena (e.g. football), a spontaneous coalescing of patriotic sentiments consumes the nation whenever Team Nigeria engages another country in a competition. These all happen without any formal legislation. Thus, by looking critically at our policy options, we can determine if they are consistent with the dominant values and culture of the society, whether it is in tandem with the ideology of elites and most influential professional groups in the society, and whether it is based on objective evidence of what is.

\subsubsection{Institutions}

Institutions are the formal and informal constraints on political, economic and social interactions. They are the rules, enforcement mechanisms and organizations. Institutions are the incentive systems that structure people to behave in certain ways; their effectiveness structure economic, political and social activity and provide incentives to the market 
(Effiom \& Ubi, 2015; North, 2005). Thus economic progress and social change take place within an institutional context, either for good or for bad depending on the dominant institutional bias. While formal institutions are visible and include our courts, police, laws, legislature, etc., informal institutions are behavioral regularity based on socially-shared rules, usually unwritten, that are created, communicated, and enforced outside of officially-sanctioned channels. They are by nature intangible and consist of customs, beliefs, values, conventions, and norms of a society. Arguably, they are more powerful than its formal counterpart (Effiom \& Udah, 2014).

In this connection, the quality of institutions constrain policy development and choices, and sometimes create path dependence, a concept which describes how institutions and actors perpetrate past but discredited and unworkable policies even in the face of better alternatives. In the words of Levi (1997), "once a government has started down a track, the costs of reversal are very high" because vested interest of stakeholders would be challenged in doing so.

\section{Ethnic Pluralism and Economic Development/ Industrialization in Nigeria}

In both the introduction to this paper and in a part of the theoretical frame work, we have tried to deal in part with the main issues of concern. With the theoretic established, we now turn to the empirical aspects. It is not as if there is no industrialization in Nigeria despite the presence of the reality that there is ethnic pluralism or even ethnic conflict. There is, but given the demands of modern economy and society, its scale, that is the scale or level of contribution of industrial production to the overall economic performance, is low. For instance, between 1981 and 1985 the average percentage contribution of industry to the GDP was $24.89 \%$, increasingly marginally to $27.99 \%$ and $28.06 \%$ between 1986-1990 and 1991-1998 respectively. However, with the return of the country to democratic rule, the contribution of the industrial sector fell to $22.22 \%$ and 19.73 between the periods 1999-2007 and $2008-2016$ respectively (Effiom \& Okoi, 2018).

In modern economic history, two possible sources or elements can and do bring industrialization. Chronologically, the first was private individuals in England. Much later in a large scale, the state in the Soviet Union, before the phenomenon of the Depression of the 1930's arising from the inescapable contradictions of capitalism, which forced it on non-socialist states in what became a mixed economy following the prescriptions of John M. Keynes. Given this fact, there is in history three main ways or agents of industrialization. The first one is private business firms or corporations. The others are the state, and the state and private sector, both engaging in ownership and running of industrial enterprises. Of late, we have the public private partnership (PPP).

So far, the government in Nigeria at various tiers especially at the federal and the regional/state level, have been undertaking a number of industrial development. Let us assume hypothetically as valid, that based on the modernization thesis, ethnic pluralism is the bane of industrial development in multi-ethnic states. Let us also assume that government at the federal level makes some efforts to industrialize. One way of establishing the fact that industrialization is discriminatory, is the location of industries. This is in recognition of standard rule that siting industrial establishment takes a number of factors, such as nearness to sources of raw materials, nearness to market, and nearness to sources of overhead cost, together with transport, and logistics and communication facilities.

A look at the industrial map of Nigeria especially at the early years, showed some effort at the federal level to establish some industrial infrastructure like the Kainji dam on the Niger, power structure at strategic locations, cement factories in Ewekero in the West, Ngalagu in the East, and later, Calabar in the East. Cement is one of the foundation industries for any country. In addition, there were the textile industries in the North-East and in the West following the availability of abundant raw materials and skilled manpower. Later on, more others like the iron and steel in Ajaokuta in the Middle Belt region of the country, the Oku Iboku paper mill in Itu, (South-Eastern minority area) and vehicle assembly plant in Kaduna and Enugu were established. These were just some of the industrial establishments under the federal government.

Apart from the argument by Diji (2004), as well as Roberts and Azubuike (2004) that the original report for the siting of the iron and steel industrial facilities was in favour of Onitsha, no other evidence is available that any ethnic connotation, punctuated the location of the industrial facilities or any other major one by the federal government. Even then in strict business or economic sense, it is difficult for the argument of these three to persuade anyone. Better still, if Onitsha were a better location, one wonders why there have not been further investments in iron and steel by other foreign firms, state governments, nor from other private initiatives, long after the take-off at Ajaokuta.

Aside from the federal government initiatives, there was regional government which competed energetically with one another in all aspects of development within their competence, and that included industrial development. If the hypothesis that ethnic pluralism or even rivalry were responsible for the slow pace of (industrial) development, given the fact that the three major ethnic groups coincided with the tripodal regional structure, and given the relatively 
enormous control of economic resources within the context of the principles of derivation, are there some significant and compelling proofs that these regimes, anchored on the dominant ethnic interest of the dominant ethnic groups in each, had shown that the gap left by the federal government was filled by them in their various regional enclaves? In simple terms, if the dominant ethnic elite from the three regions felt that there was insufficient attention paid to them by the federal government in siting industries in their regional domain, how much effort did each make to fill this gap? Except for Chief Obafemi Awolowo in the Western region with his incubutive centre for industrial development in the region, no such enclave exist. Even then, it is not clear that the Western Regional Government did that as a reaction to perceived marginalization by the Federal Government. So, here again, at the regional level of analysis, the hypothesis that ethnic rivalries are the bane of (industrial) development cannot be sustained.

From inception, government was or has always been guided by the policy of development based on the mixed economy principle by which both the public and private sectors co-exist. Our point of departure here is that ethnic pluralism results in ethnic rivalry and this in turn militates against (industrial) development. This presupposes that ethnic groups are politically organized. They have more or less common interest as a group. They operate at the environment characterized by ethnic rivalry over allocation of values. The relationship with others, the out-group, is also competitive if not antagonistic. As can be seen in the foregoing argument, the Federal Government exist and pursues industrial development policies. Regional and (later) state governments also exist based on federal system principles. The door for development has always been open for private sector participation in investment and development. One would have expected that a seriously aggrieved group of ethnic, regional or state elite, would direct their anger for being left out, by filling the gaps of industrial investment in their respective domain. But is this the case? Even after indigenization, privatization and other neo-liberal, market and private sector-driven economic policies, the country is yet to witness a massive response from this sector as a proof of the dominant thesis. If we were to stretch the pursuit further and face the risk of digression, we would have questioned the logic of thinking that modern economic development based on profit considerations, obey the laws of narrow ethnic satisfaction, especially in resources management, and this includes allocation of industries.

The above argument does not in any way, dismiss the fact that individuals in the different parts of Nigeria, had made some contributions to industrial development. One that immediately comes to mind is Adetola, associated with manufacturing of bicycle tyres, but such now exist only faintly in public memories. There was also the Dantata Group in the North as the first generation industrialist before the age of Dangote, Innoson and the rest. Even then, there is no evidence that these private industrial initiatives were taken to satisfy ethnic, rather than corporate, business needs.

The essence of this unit was to subject the ethnic pluralist thesis to critical scrutiny, from historical, empirically verifiable and logical analysis to see how sustainable it is to guide a study of the phenomenon of underdevelopment in the area of industrialization. So far, it is not sustainable.

\section{Trends and Development Plans Analysis}

A political economic analysis of Nigeria's industrialization seeks to describe the various socio-economic, cultural, political, historical, and institutional processes which influence the kinds of policies and the mechanisms deployed in achieving industrialisation for Nigeria. It is, in the main, a discourse of the competing normative issues, be they model, theories, etc. which inform the choices which the bureaucracy and the government of the day make in drafting our industrialization trajectory. Such choices have normally dovetailed into a unity of purpose by the bourgeoisie elites in foisting on the rest of the country policies congenial to their capitalist interest, with the interest of the average Nigerian mostly relegated to the background. It defines the interconnected relations between politics and economics and how the relevant social dynamics, including corporate behaviours and values, the intangible, unseen but dominant informal institutions, conspire to produce the technological and economic conditions Nigeria has today. The outcome of these interacting factors is evidenced in the various plan documents and policies initiated since Nigeria's political independence. A taxonomy of the phases of Nigeria's industrial experience is here presented.

The process of industrial development in Nigeria may be categorized into four phases after independence (Mordi, Englama and Adebusuyi, 2010). The first phase (Table 1) which commenced soon after independence was characterized by the implementation of inward looking policies of Import Substitution Industrialization (ISI) of which the Indigenization Decree (1972) provided legal backing. A major objective of this decree was to ensure Nigerians gained control of the commanding heights of the economy. Another feature of this period was the centralization of industrial planning and excessive government involvement in industrial activity. Some aspects of this policy were viewed largely to be successful, evidenced by the increase in the percentage contribution of manufacturing output to GDP from 4.8\% in 1960 to $8.6 \%$ in 1979 (Udoh, et al 2011; Ndebbio, 1991). 
Phase two was the oil burst era (1980-1985), when the glut in the international oil market reduced drastically Nigeria's foreign exchange earnings, thus impacting negatively on industrial activities. Consequently, the naira fell relative to the dollar, capital inputs into the manufacturing sector became scarce as a result of high exchange rate, capacity utilization in industry fell and by 1985 the percentage share of industrial output in GDP fell to $26.8 \%$ as against $40.1 \%$ in 1980 . Within the period, industrial sector growth rates recorded negative figures of $-21.7 \%,-8.7 \%$ and $-5.7 \%$ from 1981, 1982, and 1983, respectively (CBN Statistical Bulletin, 2008).

Phase three was the structural adjustment period (1986-1998) in which government sought to rationalize its role by reducing direct participation in industrial activities. Performance of the industrial sector worsened further due mainly to the monetary and trade policies that were pursued. The naira was left to compete freely with the dollar at the Second Tier Foreign Exchange Market (SFEM). Thus foreign exchange became scarce, naira to the dollar exchange rate depreciated; industrial inputs, which were mostly imported capital goods soared in prices and impacted negatively on the manufacturing sub-sector. Expectedly, the industrial sector which recorded a positive growth rate of $26.0 \%$ in 1985 drastically posted a negative growth of $-10.6 \%$ in 1986, the very year SAP was introduced. Capacity utilization fell steeply from 73.3\% in 1981 to 38.8\% in 1986 (CBN Statistical Bulletin, 2008).

Finally, phase four (1999- till date) is regarded as era of the consolidation of structural reforms. Within this period, four key economic consolidation packages have rolled out: the National Economic Empowerment and Development Strategy (NEEDS); Seven Point Agenda, Transformation Agenda, and Nigeria Economic Recovery and Growth Plan (NERGP, 2017-2020). The second and third are generally regarded as politico-economic slogans by the ruling party defining their economic blueprint. Besides these, Nigeria's Vision 20:2020 was launched as the long term macroeconomic policy tool to drive development in the economy. Indeed, Nigeria's current industrial policy is defined by this Vision, and more specifically by the NERGP, which includes global competitiveness in manufacturing and industrial activities. It strives to link the primary sector with the domestic, external, and services sector for greater employment generation. For instance, the NERGP projects that the manufacturing sector would grow at an annual mean rate of $8.5 \%$, i.e. from $-5.8 \%$ in 2016 to $10.6 \%$ by 2020 .

Table 1. Industrialization episodes in Nigeria

\begin{tabular}{|c|c|c|c|}
\hline $\begin{array}{c}\text { Post-Independence } \\
1960-\end{array}$ & $\begin{array}{c}\text { Oil Burst } \\
(1980-1985)\end{array}$ & $\begin{array}{c}\text { SAP } \\
(1986-1998)\end{array}$ & $\begin{array}{c}\text { Consolidation of Structural } \\
\text { Reforms } \\
\text { (1999-till date) }\end{array}$ \\
\hline $\begin{array}{l}\text { - Import } \\
\text { Substitution } \\
\text { Industrialization } \\
\text { (ISI) } \\
\text { - Indigenization } \\
\text { Decree 1972 } \\
\text { - Centralization of } \\
\text { industrial planning } \\
\text { and excessive } \\
\text { government } \\
\text { - Increase in the } \\
\text { percentage } \\
\text { contribution of } \\
\text { manufacturing } \\
\text { output to GDP } \\
\text { - Dependence on } \\
\text { foreign technology }\end{array}$ & $\begin{array}{l}\text { - } \begin{array}{l}\text { Collapse of } \\
\text { international oil } \\
\text { market }\end{array} \\
\text { - Rise in exchange } \\
\text { rate, lower oil } \\
\text { earnings, rising } \\
\text { national debt } \\
\text { surging imports, } \\
\text { lower exports, } \\
\text { capacity } \\
\text { underutilization } \\
\text { - Lower percentage } \\
\text { share of industrial } \\
\text { output in GDP } \\
\text { - Negative growth } \\
\text { rates of the } \\
\text { industrial sector }\end{array}$ & $\begin{array}{l}\text { - Rationalization of } \\
\text { incentives system } \\
\text { - Liberalization of the } \\
\text { economy } \\
\text { - Reduction of the } \\
\text { public sector, } \\
\text { greater role of the } \\
\text { private sector } \\
\text { - Second Tier Foreign } \\
\text { Exchange Market. } \\
\text { Weakening of the } \\
\text { naira } \\
\text { - Poor performance } \\
\text { of } \\
\text { manufacturing and } \\
\text { industrial sectors }\end{array}$ & $\begin{array}{l}\text { - NEEDS as the main } \\
\text { policy tool. } \\
\text { - Wealth Creation; } \\
\text { Employment } \\
\text { Generation; Poverty } \\
\text { Reduction; Value } \\
\text { Re-Orientation; } \\
\text { Reforming government } \\
\text { and institutions; } \\
\text { Growing the private } \\
\text { sector } \\
\text { - Seven Point Agenda } \\
\text { - Transformation } \\
\text { Agenda } \\
\text { - NGV20:2020 }\end{array}$ \\
\hline
\end{tabular}

Source: Authors Review of Literature 
In evaluating the relative performance of these industrial phases, we must bring within this orbit the various national development plans (NDP), which spanned these phases, beginning from the first, 1962-1968. For instance the ISI strategy adopted as the industrialization instrument in the first plan was adjudged a failure (Chete, et al., 2014), because though the ISI policy placed premium on skewing the ownership structure of industrial concerns in the country in favour of Nigerians, there was however extreme dependence on foreign technology to drive the industrialization process. In fact the domestic factor endowment were not taken into consideration in the overall industrial strategy, nor were the problems of technology transfer and acquisition overcome. These challenges re-echoed in subsequent plans and have punctuated Nigeria's industrialization efforts over the decades. Similar challenges dogged the Second NDP, 1970-1974. Specifically, Nigeria's weak and shallow technological base, traced to scarcity of human capital and relevant skill-set, constrained and stagnated the economy within the elementary phases of industrialisation; and today most of the industrial projects executed in this era have either been closed down or are operating sub-optimally.

As with the previous plans, The Third NDP (1975-1980), relied heavily on public sector investments in industrial projects. Major trends exhibited within the plan period were relative access to foreign exchange by private firms, fuelled principally by the oil boom; investment by private firms in light consumer industrial projects which depended heavily on imported machinery and raw materials; and, the transplantation of technology into the economy. In the end, the plan did not impact significantly on Nigeria's industrial capacity. The Fourth NDP (1981-1985), launched on the heels of the global economic recession was dead on arrival, because of the negative consequences of the recession on all macroeconomic indices. With crumbling oil prices, low government revenues, rising imports, and weak industrial structure - an alternative economic framework was inevitable. Thus, by 1986, the structural adjustment programme was launched as an alternative economic blueprint.

While the SAP was meant to correct the ills that bedevilled the economy from inception, its ideological underpinning was neoliberalism which reflected in its objectives of reducing the dominance of the public sector, liberalisation of financial and trade policies, and encouraging private sector led industrial development. The practical outworking of this policy was the massive sales of public enterprises to cronies of the government and allies of the ruling bourgeoisie in the name of privatisation, as well as the retrenchment of public sector workers. All these led to further social discontent, poverty, inequality and economic misery. Its key industrialisation instrument was the science and technology (S\&T) policy. According to (Chete, et al., 2014), "the S\&T policy marked the beginning of the recognition of S\&T efforts as a vehicle for successful industrial development in Nigeria." However, for several reasons, among which is the lack of integration of S\&T institutions, products and activities with the rest of the economy, the policy failed.

The above taxonomy of the different macroeconomic policy regimes which largely influenced the evolution and performance of the industrial sector from Independence were themselves by-products of a basic structural dynamic, namely, the institutional arrangements or patterned relationships which existed and still exist within the ruling elites, irrespective of political affiliation or nature of government (democracy or dictatorship). A cursory appraisal of the different plans and policies highlighted above shows that our industrialisation path was drafted mostly by the military oligarchy, strengthened by their civilian collaborators. The success of a policy is however not only dependent on who drafts it, for as evidenced above, even the ones articulated by a purely civilian regime has not fared better.

Table 2 highlights the performance of key industrial sector variables within a slightly modified policy regime, following Okuneye et.al. (2001). Categorized into six industrial policy regime phases, Regime 1(1970-1973) was the post-civil war reconstruction period; Regime 2 (1974-79) coincided with the Second NDP and oil boom; Regime 3 (1980-1985) fell within the Third NDP; Regime 4 (1985-1993) spanned seven years of liberalization policy via the SAP; Regime 5 (1994-1999) was the time of consolidation of the contestable gains of SAP; and finally, Regime 6 (1999 to 2015), the period of civil governance and implementation of several industrial policies already highlighted above. A key feature of industrial sector and manufacturing subsector trends is the dismal shares of the manufacturing subsector in total GDP and manufacturing exports in total exports. For the former, its share has been in the single digit since 1973 to date, while for the latter it has been less than one percent for the most part. 
Table 2. Average values of industrial sector production performance/trade characteristics under policy regimes

\begin{tabular}{|c|c|c|c|c|c|c|c|}
\hline \multirow[t]{3}{*}{$\mathrm{S} / \mathrm{N}$} & & \multicolumn{6}{|c|}{ Policy Regimes } \\
\hline & & Regime 1 & Regime 2 & Regime 3 & Regime 4 & Regime 5 & Regime 6 \\
\hline & & $1970-73$ & 1974-79 & 1980- 85 & $1986-93$ & 1994-99 & 1999-2015 \\
\hline 1 & $\begin{array}{l}\text { Index of Industrial } \\
\text { production }\end{array}$ & 57.7 & 88.8 & 107.58 & 124.59 & 130.74 & 139.4 \\
\hline \multirow[t]{5}{*}{2} & \multicolumn{7}{|l|}{ Indices of : } \\
\hline & a) Manufacturing & 29.43 & 59.02 & 105.13 & 146.25 & 137.86 & 126.6 \\
\hline & b) Mining & 109.4 & 138.63 & 99.4 & 108.8 & 126.68 & 135.1 \\
\hline & \multirow{2}{*}{ c) Electricity } & 25.55 & 53.87 & 90.55 & 132.68 & 146.48 & 182.0 \\
\hline & & & & & & & \\
\hline \multirow[t]{2}{*}{3} & \multirow{2}{*}{$\begin{array}{l}\text { Share of Manufactured } \\
\text { Exports as a proportion of } \\
\text { total exports }(\%)\end{array}$} & 3.96 & 0.88 & 0.46 & $(1989-93)$ & 0.16 & (2004-14) \\
\hline & & & & & 0.22 & & 10.81 \\
\hline \multirow[t]{2}{*}{4.} & \multirow{2}{*}{$\begin{array}{l}\text { Value of Manufactured } \\
\text { export ( } \mathrm{N} \text { million) }\end{array}$} & 50.9 & 59.87 & $(1983-85)$ & $(1989-93)$ & 1705.1 & $(2004-14)$ \\
\hline & & & & 49.03 & 328.62 & & 62401.7 \\
\hline \multirow[t]{2}{*}{5} & \multirow{2}{*}{$\begin{array}{l}\text { Manufacturing share in GDP } \\
(\%)\end{array}$} & 7.45 & 5.57 & $(1981-85)$ & 8.15 & 6.56 & 4.43 \\
\hline & & & & 9.17 & & & \\
\hline \multirow[t]{2}{*}{6} & \multirow{2}{*}{$\begin{array}{l}\text { Manufacturing } \\
\text { utilization (\%) }\end{array}$} & $(1970-71)$ & $(1975-79)$ & 56.63 & 40.38 & 31 & 52.7 \\
\hline & & 74 & 75.42 & & & & \\
\hline
\end{tabular}

Source: Adapted from: Adebiyi \& Dauda (2004)

CBN Statistical bulletin (Various Issues)

CBN Annual Report and Statement of Account (Various Issues)

Table 3. Manufacturing value added as a \% of GDP of selected countries

\begin{tabular}{rrrrrr}
\hline & \multicolumn{1}{c}{ China } & Indonesia & \multicolumn{1}{l}{ India } & \multicolumn{1}{l}{ Kenya } & \multicolumn{1}{l}{ Nigeria } \\
\hline $1981-1990$ & 38.6 & 16.3 & 16 & 12 & 8.5 \\
$1991-2000$ & 39.8 & 24.4 & 15.6 & 11.5 & 7.2 \\
$2001-2010$ & 40.3 & 27.2 & 15.2 & 12.4 & 3.2 \\
$2011-2015$ & 36.6 & 21 & 17.4 & 11.8 & 8.6 \\
$2016-2019$ & 27.8 & 20.1 & 14.6 & 8.2 & 9.6 \\
\hline
\end{tabular}

Source: World Development Indicators (World Bank, 2016)

Table 3 reveals that Nigeria's average manufacturing subsector contributed the least in value added to GDP amongst the list of selected Countries.

\section{Comparative Indigenous Technological and Economic Strengths}

Yet, in spite of the serial and perennial damage done to Nigeria's industrial and economic advancement by the minority governing elitist and predatory class, the God-given technological proclivities of Nigeria's indigenous nationalities still hold out hopes of a redeeming economic future, namely, that all is not lost. Thus, as submitted by Siyanbola, et al., (2012) "Nigeria's indigenous technologies present significant opportunities for local economic transformation and, to some extent, for global competitiveness". It must be emphasised that no nation has industrialised by solely relying on imported or foreign technology; the latter becomes fruitful when complemented with a robust dose of its local counterpart. The development of local industrial and technological capacities provides 
the basis for leveraging on foreign technology. Table 4 presents, among other features, the relative indigenous technological strengths of Nigeria.

Table 4. Selection of key mineral types, indigenous technology and their locations

\begin{tabular}{|c|c|c|c|}
\hline \multirow[t]{2}{*}{ Regions } & \multirow{2}{*}{$\begin{array}{l}\text { Indigenous } \\
\text { Technology }\end{array}$} & \multirow[t]{2}{*}{ Mineral Resources } & States $\quad$ hosting \\
\hline & & & Technology/Minerals \\
\hline North-West & Leather Tanning & $\begin{array}{l}\text { Columbite, Gold, Tantalite, } \\
\text { pegmatite, Uranium, cotton, }\end{array}$ & $\begin{array}{l}\text { Sokoto, Zamfara, Kano, } \\
\text { Jigawa, Kaduna }\end{array}$ \\
\hline North-Central & & $\begin{array}{l}\text { Iron ore, Uranium Coal, } \\
\text { Limestone, Marble, Gypsium }\end{array}$ & Kogi, Plateau, Benue \\
\hline North- East & Leather Tanning & Uranium, & $\begin{array}{l}\text { Borno, Adamawa, Taraba, } \\
\text { Bauchi, }\end{array}$ \\
\hline South- East & $\begin{array}{l}\text { Blacksmithing } \\
\text { Iron smelting } \\
\text { Wood carving }\end{array}$ & $\begin{array}{l}\text { Coal, Gold, Limestone, Lead, Zinc, } \\
\text { Salt, }\end{array}$ & Enugu, Abia, \\
\hline South-West & $\begin{array}{l}\text { Aluminum Pottery } \\
\text { Blacksmithing }\end{array}$ & $\begin{array}{l}\text { Bitumen, Phosphate, Limestone, } \\
\text { Coal, }\end{array}$ & Oyo, Lagos, Ogun, Ondo \\
\hline South-South & Bronze Casting & $\begin{array}{l}\text { Uranium, Bitumen, Limestone, } \\
\text { Manganese, Iron ore, Gold, }\end{array}$ & $\begin{array}{l}\text { Edo, Cross River, Akwa } \\
\text { Ibom, Delta, }\end{array}$ \\
\hline
\end{tabular}

Source: Authors' review of Literature

It can be seen that none of the geopolitical regions is simultaneously lacking in indigenous technology and in a key mineral resource which can be harnessed for the industrial and economic good of the nation. Within the ethnic tripod of Nigeria, together with other ethnic minorities, a harvest of indigenous capacities can be found. Nigeria is abundantly blessed that her cultural plurality and heterogeneous indigenous technology should be a potent incentive to industrialization and economic growth than a curse.

With regards to mineral resources, Nigeria plays host to 44 confirmed mineral types (NERGP, 2017) with varying differentials in quantity and quality spread across the geopolitical and ethnic space of the country (see Figure 2). Specifically, in the North-west and North-central zones, there is a huge concentration of high value gold reserves; in the South-west, particularly Ondo State and the Niger Delta, there is a preponderance of bitumen; in the North-central, large deposits of mid-grade to high-grade iron ore can be found; in the Enugu-Benue-Kogi axis, there are massive reserves of coal of high quality; and in the North-east, there are precious metals deposits of different grades. In fact, due to the country's skewed concentration in the oil sector, much of Nigeria's mineral deposits have remained unexplored and underutilized. No serious investment have been undertaken in that sector over the years. 


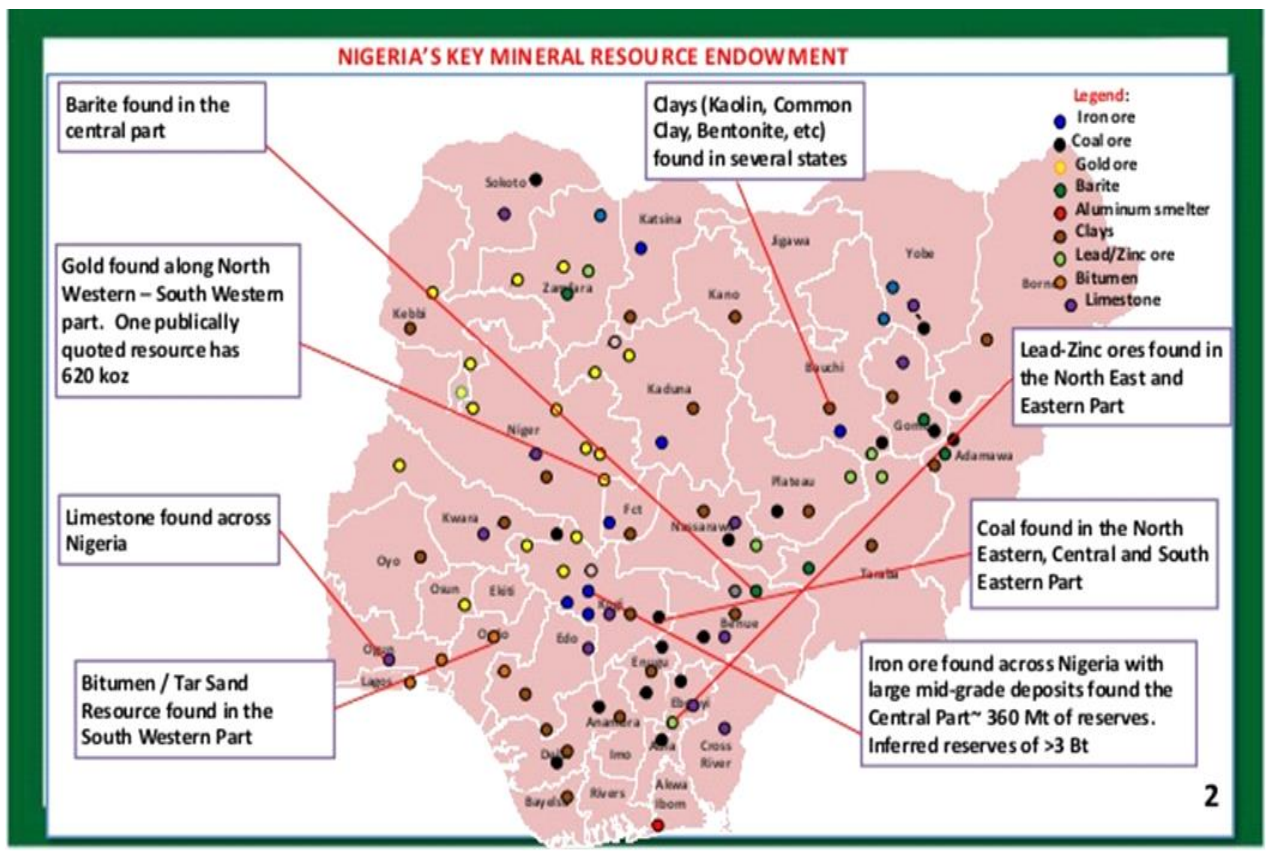

Figure 2. Nigeria's key mineral resource endowment

Source: Ministry of Mines and Steel Development

\section{Nigerian State Policy Responses to the Challenge of Industrial Development}

Industrialization as an aspect of economic development of societies cannot be overemphasized even in the era of artificial intelligence or Nano technology. Farming and later modern agriculture had been the foundation of human physical existence and reproduction of life in the society. Industrialization is the inevitable by-product of the scientific revolution that took place in England in the $18^{\text {th }}$ century. Ekpo (2004) and Zurekas (2001) have confirmed that there are three broad outcomes that industrialization process have brought about: consumer goods are guaranteed, capital goods are produced which also enable the production of more consumer goods, and lastly, social or overhead capital. All economies, advanced or evolving, seek the benefits of industrialization, because nature and investors expect from industrialization, greater benefits of economic growth and development. To this end, the industrialization process being a complicated phenomenon involving technical, social, human, cultural, institutional, as well as political dimensions, has been formalized in various models and theories so that some economists especially of the liberal capitalist persuasion, could replicate and control its growth trajectories (Rostow, 1960; Romer,1986, 1990; Schumpeter, 1942).

This section focuses on the policy responses of the Nigerian state and government to the challenges of industrialization as the key to economic development and thus, improvement in the standard of living of the members of the society. We look critically at the various stages in the economic development of the country and how the industrial policies are factored into them.

\subsection{Industrial Infrastructure as Foundation for Development}

Nigeria inherited a hostage economy from the British colonial regime. The economy was, more or less, and is still taken captive by a regime of structured global division of labour in which the peripheral formation supply the raw materials in return for finished goods from the metropole. (Ake, 1981; Baran, 1957). Ake's (1981) study of the post-colonial political economy of Nigeria elaborates on the peculiar nature of this kind of development, where both the infrastructure, raw materials, centre of economic activities and economic sectors are skewed to meet external needs and imports. For instance, very faint efforts were made towards processing of agricultural raw materials. Exporting raw materials in their raw, natural forms, parallel rail and road links in vertical forms from the North through the centre of collection together with minerals, to the coast. Ake (1981) argues that the colonial economy was characterized by disarticulation such that parts and sectors were not complementary. This is opposed to the articulated economy in which there is regional and/or sectoral complementarity and reciprocity. The example given is that if one region specializes in agriculture, the other does so in manufacturing of goods whose raw materials are 
provided by the region that specializes in agricultural production. Ironically, while this kind of reciprocity was structured to elude the colonial economy, that was exactly what prevailed at the international economic level, based on the doctrine or the law of comparative advantage in the Ricardian classical political economy. Ake (1981) also observes that not only was the colonial economy so disarticulated, it also lacked the critical element of forward-backward linkages in production that links one area of production of industrial goods to depend on or stimulate the production of relevant minerals as its raw material. Similarly, a mineral as raw material, could result in the production of industrial, finished goods as its product.

We consider it important not to exclude such background information without which our accounts and analysis would be considered as superficial and rootless. It is the knowledge of the nature of the colonial past that can supply our analysis with the appropriate tools to describe and analyze the phenomenon in question.

Nigeria inherited a very weak economic infrastructure and foundation. It inherited an economic structure that was skewed to serve outside interest and markets. It inherited an economic system structured to depend for its existence, on foreign supplies; it inherited an economic system of dichotomized agricultural products which was skewed in form of "cash crops" in a cash-crop-food -crop dichotomous format. This dovetails into the phenomenon of chronic food shortages after Independence and reaches its peak at the high noon of oil boom in the 1970s. This is how history affects the present, as well captured in the theoretical framework of this article.

Economic development is not just limited to economic factors. As indicated earlier, it is affected by social, political and cultural factors as well. In the Marxist variant of explaining phenomena in society, we had shown that among others such as history and the economic or material base of society, development is also affected by the leaders' perception and how the leadership understands and responds to environmental stimuli. The post-colonial state was the inheritance of a class of indigenous ruling class of the extant elite that had all the full compliments of the colonial state (ruling class) in ideology and perception, more or less with minor variations. The state bureaucracy with its two wings namely: the civil and the armed were inherited. All the apparatus of coercion, the civil and the armed bureaucracy, the judiciary, the court and the laws as well as the institutions that enforced them, were all inherited and received. When all these are added to the economic institutions, patterns of organization, lame infrastructure, limited investment, and a largely unskilled labour force, except in the state bureaucracies, the picture of the post-colonial Nigeria becomes clear enough for any analysis such as ours. In the absence of a radical or revolutionary national elite functioning through a significant political party, it would be futile to expect a miracle from the local wing namely, the inheritor ruling class, which, though running a state with formal independence, was and still is dependent upon the external component of the ruling class in what Ake refers to as 'flag and anthem' independence. That is the brief background to our analysis in this unit of the paper.

\section{The Adoption of the Structural Adjustment Program (SAP) and Neo-colonial Dependence}

Adoption of SAP constituted some sort of a mile stone in the pursuit of industrial policy not only in Nigeria but elsewhere in the world where the policy was either appealing to the decision making elite in government and their ruling class, or it was forced on the government by donor agencies operating through the institutional framework of international financial regimes like the World Bank and the International Monetary Fund. This policy was offered for adoption to the civilian government under President Shehu Shagari, but the government was afraid of the adoption of a policy whose implementation negatively targeted the majority of the electorate namely the working class and the poor. It was suppressed by the government and even by the military government that toppled it. It was not until what was suspected to be a foreign-sponsored, far-right counter coup led by Gen. Ibrahim Babangida that the policy was floated and adopted brutally in the second half of the decade of the 1980's. The key objective for the adoption of the SAP was to ensure that economic development was "private sector-led".

In terms of evaluation, just like the ISI was more or less a failure to the extent that it failed to lay the foundation for industrial development, the adoption of SAP has not in any significant way pushed the Nigerian industrial frontiers to new limits. Though some pro-establishment and conservative narratives like Eminue (2005), applaud the policy, it is hard to see the evidence of its significant impact on the industrial development of the economy. Quoting the official SAP document, the principal aim of the program was put thus:

The programme aims at altering aggregate domestic expenditure and production patterns so as to minimize dependence on imports, enhance the non-oil export base and bring the economy back to the paths of steady and balanced growth (Five years of the Babangida Administration). 
As observed under the ISI, the strength of the economy became even more deflated by virtually depleting the scarce foreign exchange in import of the industrial input from the metropole which the manufacturing firms were owned. Similarly, apart from the high social cost of sacking of hundreds of thousands of workers from government parastatals, ministries and other establishments, the introduction of SAP has significantly continued till this day to weaken the economy by depleting the strength of the local currency through its devaluation as the key element of the IMF conditionality. While this weakened the currency, it also cheapened the price of the available raw materials for export, hence reducing the stock of foreign exchange available to the government. The other logic of devaluation was to encourage more export. This seemed to be a near-sighted reasoning if juxtaposed with an established fact that up to $95 \%$ of foreign exchange came from the crude oil sales. This commodity was available in the market with the control by the Organization of Petroleum Exporting Countries (OPEC), the cartel that Nigerian oil production volume was dependent on, and which fixed the quota for production for each member including Nigeria. So it becomes very difficult to see the basis for the optimism in this regard. In addition to this, as observed by Ndebbio and Ekpo (1991), the nature of Nigeria's dependence makes it impossible for it to export anything outside raw materials from agriculture or crude oil. They observe that industries in the country are dominated by consumer goods, because indigenous capitalist and the multinational corporations find it easier to make more profits from such industries.

One of the objectives of the SAP was the diversification of the economy. Unfortunately, the way the architects of the program projected it was as if no previous attempts had been made to diversify the economy before the adoption of the SAP, but as Toyo (1984) has observed, all of the pioneer industry schemes which was expressed in heavy investment in the development of infrastructure and effort to attract foreign investments, have yielded the fruits they could yield. Ndebbio and Ekpo (1991) conclude that all hitherto export-led development policies such as ISI and all its derivatives are all based on and aimed at achieving diversification of the economy. The question then is, given these previous measures directed at achieving the same goal, is the adoption of the SAP not superfluous? Most likely it is, even as it can be argued that diversification is just one aspect of the objectives of SAP.

From what we have discussed as a critical evaluation of the SAP so far, little is added to the economy in terms of private-sector industrial development. Rather there is a steady decline such that by 2011, the contribution of the manufacturing sector to the GDP was only 4\% (CBN 2012). This means that the domestic economy was unable to generate sufficient thrust to strengthen the privatized enterprises and industries disinvested by government at various levels. Ogbonna and Uma (2017) have listed both the light and heavy industries established in response to the ISI policies prior to the SAP to include petro-chemical industries in Port Harcourt, Pulp and Paper mill in Calabar. Iwopin and Oku Iboku, cement in Ngulagu, Calabar and Ewekoro, oil refineries in Kaduna and Warri. Others in the heavy industries class include Iron and steel in Ajaokuta, Aladja, Jos, Kaduna and Oshogbo. It is common knowledge that some of these industries have since been abandoned. Ogbonna and Uma (2017) attributes the failure of most of these industries to shortage of funds to import the critical foreign inputs because of low demand for oil in the oil glut years in the 1980's. This too raised the exchange rate to complete tatters and among others, Nigeria's debt profile rose and an illusory logic ensued which made the creditors, the local governing elite and worse still, the academia, to focus on the shadow and ignore the substance.

All the parties involved were either hypocritical, or grossly ignorant of the fact that much of the problem that manifested in the scenario depicted in the preceding paragraph, was rooted in the system on which the Nigerian economy was founded - dependence on external economies. However, it is not the dependence that is the key issue despite popular beliefs and conviction. The reality is that the capitalist system on which the Nigerian economy is dependent, is prone to periodic booms and upheavals in which the economists describe with beautiful words as business cycle. As is known, the capitalist system experiences periodic recessions and depressions and these affect the scale of production and demand for raw material, some of which are usually supplied by the peripheral nations by way of agricultural raw materials and oil and gas. This resulted in low demand for the crude oil which did, in fact, not glut but less demanded for and the impact was promptly felt by Nigeria and it affected the functioning of its productive sector and raised the prices of its imported consumer goods. Thus, Toyo (1984) aptly describes the system:

The capitalist economy contains many paradoxes. One of them is that in order to barely attain such employment of available labour and productive capacity, investment must keep on growing. Once new investment stops, this means curtailment of orders for the output of the producer goods industries, and a decline in profit expectation. Again, prosperity raises cost and thus lowers profit expectation. Thus the boom inexorably produces the 


\section{next depression.}

Rather than face this reality in a more or less monocultural economy, the same capitalists in the metropole, through international financial regimes, sold the SAP dummy to them and our academics or most of them celebrated it. In the midst of this financial upheaval, one of the demands of the SAP was the devaluation of the naira as mentioned earlier. Among others, this weakened the capacity of the people to make effective demands and given the volume of those laid off, to fulfil the requirements of the SAP, it is not far to see the inflationary trend since the 1980s which has not significantly abated since then.

\subsection{Consequences of State Disinvestment and Foreign Dictation of Industrial Policies}

Perhaps the worst aspect or consequence of adoption of the SAP was and still remains not only the continuous devaluation of the naira since 1988 but the privatization and disinvestment by the state. For instance, the power sector which has been privatized since 2014 has gone worse by the day, making the national legislature to demand for the return to the status quo ante. Same goes for the virtual inactivity in our heavy industry sector, especially in the iron and steel sectors. SAP, in this regard, has finished up whatever was left for Nigeria to industrialize.

In our framework of analysis, we made reference to the ideological disposition of the decision makers of the state, that is, actor's perception, interpretation and response to environmental stimuli. These critical factors are playing out on policy choices and preferences as well as the approach to actualizing policy objectives. The systemic cord that binds the local wing of the Nigerian ruling class to their foreign component, is one critical factor that can be used to explain the unworkability of public policy in this sector.

The colonial state bequeathed power to a local ruling class as representatives while a structured neo-colonial nexus was woven to link the emergent class and its counterpart in the metropole. Essentially, virtually everything about the colonial economic policies have remained, even when as a cosmetic gesture, the inheritor state had its own currency. The colonial division of labour is still more or less intact just as the capitalist ideology of development centred on the market.

At Independence, the government wanted to establish iron and steel industry but the World Bank advised against it and rather encouraged the concentration with the cultivation and export of agricultural raw materials while iron and steel products should be imported. It was the exigencies of the Civil War that drove the government within the orbit of the socialist countries and which made it possible for the Soviet scientists to confirm that indeed, iron and steel industry was feasible, in contrast to the negative verdict by the World Bank. Though Obikwelu \& Nebo (2015) claim that in 2003, American based company "found its way" in Ajaokuta to run the company with disastrous consequences, the fact remains that no company can just sneak into an industrial establishment in another country and start operation, be it for good or for evil. What this means is that it got into the industry officially, though it is understood that when it became obvious that the credit for Nigeria having a successful iron and steel complex would be given to the Soviet Union, neo-colonial rules were activated and the local wing of the neo-colonial state, agreed that the complex be split into sectors leaving the Soviet with just one. That was the foundation for the destruction of the iron and steel industry in Nigeria, attributed erroneously to conventional corruption rather than strategic power play and neo-colonialism.

If we take a studied look at the types and quality of industries that Nigeria had chosen and established since Independence as listed earlier before the SAP, its disinvestment and privatization, one would not condemn the government. These are all foundation industries which are necessary for any country to be launched into the trajectory of industrial development. The only thing that was and is still relatively lacking, is the quantity and quality of human resources required. This was confirmed in the 1970-1974 Development Plan (Chete et al. 2014). The study notes that the critical quality and quantity of manpower was "shallow". For this principal reason, the plan could not move beyond the elementary stage, a factor which made government to promulgate the Nigerian Enterprises Promotion Act of 1977. They also observe that in this plan period, government invested directly in the industrial sector. It is yet to be seen if one of the key objectives of the policy, namely, encouraging businessmen and foreign investors to move from the unsophisticated sphere of the economy to the domain where large investments are required was achieved. To some extent though, investment in the areas of cement and oil refineries by the Dangote Group and in the automobile sector by the Innoson Motors can be cited, even as it is not clear if these efforts are due to this policy.

There is no way a country's government would be made to retreat from the pursuit of industrial investment policy as can be seen in the case of Nigeria and significant positive changes would be expected. The domestic wing of the ruling class has blurred vision. Otherwise, it would have realized that surrendering its investments in the industrial 
sector to private interest just because external interest demanded for it, is not in the interest of the country in the short, medium or in the long term. In an interesting comparative study of Nigeria and South Korea governments in respect of approach to industrialization, Ogbonna and Uma (2017), among others, came to the conclusion that while the Nigerian case lacks highly trained workforce, their South Korean counterparts make provision for it. Surely, unlike the withdrawn position of the government in the Nigerian case since the adoption of the SAP, the South Korean government demonstrates "unflinching aspiration to uplift the economy (aid) overshadowed every other motive".

The local wing of the ruling class in the Nigerian ruling class is oblivious of the fact that the same Western powers which have prevailed upon it to disinvest and privatize, were the beneficiaries of the Keynesian model. By it the state, from the end of the Second World War till the 1980's, operated a mixed economy model. Prior to this period, apart from the massive injection of American capital into the Western European economies, the state was there to invest, partner with the private investors, direct investment policies and provide welfare services. It was only when these states had stood firmly on their feet in terms of economic strength that they started to adopt the neo-liberal economic policies by invoking the ghost of Adam Smith. Nigeria should have focused on addressing the shortcomings noticed in the implementation of its pre-SAP industrial policies rather than yield to the Western band wagon of disinvestment.

\section{Conclusion}

In conclusion, there is nothing in the existing narratives to convince us that ethnic pluralism or even ethnic conflicts (where they exist), non-diversification or even corruption are significant explanations for the poor state of industrial development in Nigeria. Corruption, which is the most widely believed factor, has been explained as a systematic necessity encrusted in every capitalist economy, according to Ekekwe (1986). Obadina (1988), while comparing the national bourgeoisie in African and Asian continents, concluded that this class in both continents are very corrupt. He explained that in Asia, as we saw earlier in the case of South Korea, the bourgeoisie has progressively different perceptions about development than African counterparts and this includes Nigeria. "For the Asian bourgeoisie, economic activity is preeminent, overriding other aspects of society. For Africa's predator rulers, economic development is peripheral. Most of their energy is expended on fighting for the control of their countries' resources".

This is the crux of the matter. The problem lies on the world outlook of the ruling class and its neo-colonial dependence on external mentors for policy guide which runs counter to the national interest of Nigeria in general and, in particular, the attainment of significant industrial development in the country. Above all, the adoption of the SAP has proven the most devastating blow that retards investment in the industrial sector of the national economy. Being a failure so far, this policy is overdue for abandonment so that the state should re-invest.

\section{References}

Ake, C. (1981). A political economy of Africa. London: Longman.

Alesina, A., \& La Ferrara, E. (2005). Ethnic diversity and economic performance. Journal of Economic Literature, 43(3), 762-800.

Alesina, A., Baqir, R., \& Easterly, W. (1999). Public goods and ethnic divisions, Quarterly Journal of Economics, 114(4), 1243-1284.

Alesina, A., Devleschawuer, A., Easterly, W., Kurlat, S., \& Wacziarg, R. (2003), Fractionalization. Journal of Economic Growth, (8), 155-94.

Alesina, A., Spolaore, E., \& Wacziarg, R. (2000). Economic integration and political disintegration. American Economic Review, 90(5), 1276-1296.

Amin, S. (1974). Neo-colonialism in West Africa. Harmondsworth: Penguins Books.

Apter, D. (1965). The politics of modernization. Chicago University: Chicago Press.

Baran, P. (1957). The political economy of growth. Harmondsworth: Middlesex Penguin Books.

Barongo, Y. (1983). Political science in Africa: A critical review. London: Z Press.

CBN Statistical Bulletin. (2008). A publication of The Central Bank of Nigeria.

CBN Statistical Bulletin. (2012). A publication of The Central Bank of Nigeria.

Chete, L. N., Adeoti, J. O. F., Adeyinka, M., \& Ogundele, O. (2014). Industrial development and growth in Nigeria: Lessons and challenges. WIDER Working Paper 2014/019. Helsinki: UNU-WIDER.

Chinweizu. (1978). The west and the rest of us. London: Nok publishers. 
Collier, P. (2000). Ethnicity, politics and economic performance. Economics and Politics, 12, 225-45.

Diji, C. J. (2004). Constraints to industrialization: An ex-post evaluation of the iron and steel industry in Nigeria. In Challenges of Nigerian Industrialisation: A Pathway to Nigeria Becoming a Highly Industrialised Country in the Year 2015. Selected Papers for the 2004 Annual conference of the Nigerian Economic Society.

Dominguez, V. R. (1986). White by definition. New Bruriswick NJ: Rutgers University Press.

Easterly, W. (2001). Can institutions resolve ethnic conflict? Economic Development and Cultural Change, 49(4), 687-706.

Easterly, W., \& Levine, R. (1997). Africa's growth tragedy: Policies and ethnic divisions. Quarterly Journal of Economics, 111(4), 1203-1250.

Effiom, L., \& Okoi, O. B. (2018). Human capital, technological development, infrastructure, and manufacturing subsector performance in Nigeria. International Journal of Economics, Commerce and Management, 6(7), 203-231.

Effiom, L., \& Ubi, P. (2015). Informal institutions: The binding constraint on institutional efficiency in Nigeria. British Journal of Economics, Management \& Trade, 5(3), 258-272.

Effiom, L., \& Udah, E. B. (2014). Industrialization and economic development in a multicultural milieu: Lessons for Nigeria. British Journal of Economics, Management \& Trade, 4(11), 1772-1784.

Ekekwe, E. (1986). Class and state in Nigeria. London: Longman.

Ekpo, A. H. (2004). Industrialisation and Nigeria's economic development. In Challenges of Nigerian Industrialisation: A Pathway to Nigeria Becoming a Highly Industrialised Country in the Year 2015. Selected Papers for the 2004 Annual conference of the Nigerian Economic Society.

Emerson, R. (1960). From Empire to Nation. Cambridge, Mass: Howard University press.

Eminue, O. E. (2005). Public policy analysis and decision making. Lagos, Nigeria: Concepts Publications.

Fanon, F. (1966). The wretched of the earth. New York: Grove Press.

Fasan, O. (2017). The political economy explanation for Nigeria's elusive progress. Retrieved from https://www.businessdayonline.com >on 27/6/2017

Fearon, J., \& Laitin. D. (1996). Explaining inter-ethnic cooperation. American Political Science Review, 90, 715-29.

Greif, A. (1993). Contract enforceability and economic institutions in early trade: The Maghribi traders' coalition. American Economic Review, 83(3), 525-548.

Hall, P. A. (1997). The role of interests, institutions, and ideas in the comparative political economy of the industrialized nations. In M. I. Lichbach \& A. S. Zuckerman (Eds.), Comparative politics: Rationality, culture, and structure (pp. 174-207). Cambridge: Cambridge University Press.

Hansen, H. B. (1977). Ethnicity and military rule in Uganda Uppsala, Scandinavian institute or African studies Research Report No 43.

Huntington, S. P. (1968). Political order in changing societies. London and New Heuren: Yale University Press.

Kay, G. (1974). Development of underdeveloped. London .

Keynes, J. M. (1936). The General Theory of Employment, Interest and Money. London: Macmillan (reprinted 2007).

Kupper, L., \& Smith, M. G. (eds). Pluralism in Africa. Berkely: University of California Press.

La Ferrara, E. (2003). Kin groups and reciprocity: A model of credit transactions in Ghana. American Economic Review, 93(5), 1730-1751.

Lavis, J. N., Ross, S. E., Hurley, J., Hohenadel, J. M., Stoddart, G. L., Woodward, C. A., \& Abelson, J. (2002). Examining the role of health services research in public policymaking. Milbank Quarterly, 80(1), 125-154.

Lazear, E. (1999a). Globalization and the market for teammates. Economic Journal, 109, 15-40.

Lazear, E. (1999b). Culture and Language. Journal of Political Economy, Supplement, 95-125.

Levi, M. (1997). A model, a method, and a map: Rational choice in comparative and historical analysis. In M. I. Lichbach \& A. S. Zuckerman (Eds.), Comparative politics: Rationality, culture, and structure (pp. 19-41). 
Cambridge: Cambridge University Press.

Melson, R., \&Wolpe, H. (eds.) (1971). Nigeria: Modernization and the politics of communalism.

Min, B., Cederman, L. E., \& Wimmer, A. L. E. (2010). Ethnic exclusion, economic growth and civil war. Unpublished.

Moe, T. M. (2015). Vested interest and political institutions. Political Science Quarterly, 130(2). https://doi.org/10.1002/polq.12321

Mordi, C. N. O., Englama, A., \& Adebusuyi, B. S. (2010). The changing structure of the Nigerian economy. Abuja, Nigeria: Central Bank of Nigeria.

Ndebbio, J. E. U. (2006). The structural economic dimensions of underdevelopment, associated vicissitudes and imperatives: Agenda for positive change. 33rd inaugural lecture. Calabar, Nigeria: Saesprint.

Ndebbio, J. E. U., \& Ekpo, A. H. (1991). The Nigerian economy at the crossroads: Policies and their effectiveness. Calabar, Nigeria: University of Calabar Press.

Nigeria Economic Recovery and Growth Plan (NERGP). (2017). Ministry of Budget and National Planning.

Nnoli, O. O. (1980). Ethnic Politics in Nigeria. Enugu, Nigeria: Fourth Dimension Publishers.

North, D. C. (2005). Understanding the process of economic change. Princeton, NJ: Princeton University Press.

Nyong, M. O. (2017). Political economy of core formations: Ethnic diversity and economic development in advanced countries. In Bassey, C. O., \& Ndiyo, N. A. (Eds.), Political economy of global formations: Nexus of Poverty and underdevelopment crisis in core-periphery relations (pp 508-529). Concept Publications, Palmgrove, Nigeria.

O’ Reilly, C., Williams, K., \& Barsade, S. (1997). Demography and group performance. Unpublished.

Obadina, T. (1988). A Tale of two regions. Africa Today, March.

Obikwelu, D. O. N., \& Nebo, C. O. (2015). A critical look at the Nigerian steel industry ----a dark page on the history of Nigeria and the metallurgical profession. https://doi.org/10.13140/RG.2.1.1215.0486

Ogbonna, B. M., \& Uma, K. E. (2017). Restrategising Nigeria's industrialisation and industrial policy for economic recovery: Lessons from South Korea. International Journal of Research in Management, Economics and Commerce, 7(7), 88-97.

Okuneye, P. A. et al. (2001). Environmental impact of trade liberalization: The case of Nigeria's cocoa subsector. In Natural Resource Use the Environmental and sustainable development (pp. 147-174). Selected papers presented at the 2001 Annual conference of the Nigerian Economic society.

Payne, R. J., \& Nassar, J. R. (2008). Politics and culture in the developing world. In The impact of globalization (3rd ed.). New York: N. Parson Longman.

Pomey, M. P., Morgan, S., Church, J., Forest, P. G., Lavis, J. N., McIntoch, T., \& Dobson, S. (2010). Do provincial drug benefit initiatives create an effective policy lab? The evidence from Canada. Journal of Public Health Politics, Policy, and Law, 35(5), 705-742.

Post, K. W. J., \& Vickers, M. (1973). Structure and conflict in Nigeria, 1960-1965. London: Heinemann.

Roberts, F. O. N., \& Azuibuike, U. C. (2004). The state, politics and deindustrialization in Nigeria. In Challenges of Nigerian Industrialization: A Pathway to Nigeria Becoming a Highly Industrialised country in the Year 2015. Selected Papers for the 2004 Annual conference of Nigerian Economic Society (NES).

Rodney, W. (1972). How Europe underdeveloped Africa. London: Bogle-L' Overhere publications.

Rodrick, D. (1999). Where did all the growth go? External shocks, social conflict, and growth collapses. Journal of Economic Growth, 4, 385-412.

Romer, P. M. (1986). Increasing returns and long-run growth. The Journal of Political Economy, 94(5), $1002-1037$.

Romer, P. M. (1990). Endogenous technological change. The Journal of Political Economy, 98(5), S71-S102.

Rostow, W. W. (1960). The Five Stages of Growth-A Summary. The Stages of Economic Growth: A Non-Communist Manifesto. Cambridge: Cambridge University.

Schumpeter, J. (1942). Capitalism, socialism and democracy. New York: Harper.

Scully G. W. (2005) Multiculturalism and economic growth. NCPA Policy Report: No196. 
Siyanbola, W. O., Egbetokun, A. A., Oluseyi, I., Olamade, O. O., Aderemi, H. O., \& Sanni, M. (2012). Indigenous technologies and innovation in Nigeria: Opportunities for SMEs. American Journal of Industrial and Business Management, 2, 64-75. https://doi.org/10.4236/ajibm.2012.22009

Stone, D. (2001). Policy paradox: The art of political decision making. New York: W.W. Norton \& Company.

Tajfel, H., Billig, M., Bundy, R. P., \& Flament, C. (1971). Social categorization and intergroup behavior. European Journal of Social Psychology, 1, 149-178.

Toyo, E. (1984). The causes of the depression in the Nigerian Economy. African Development, Cordesria, IX(3).

Udoh, E., Udeaja, E., \& Ebong, F. (2011). Ten years of industrial policies under current democratic administration (1999-2009): Features, successes, and challenges. In Elijah, U., Ogbuagu, U., \& Essia, U. (Eds.), Industrial development: A catalyst for rapid economic growth. Essays in Honour of John Emmanuel Ndebbio. Calabar, Nigeria: P.N. Davison Publications.

Wilson, J. Q. (1995). Organizations and public policy. In Political organizations (pp. 327-346). Princeton: Princeton University Press.

Zurekas, C. (2001) Economic Development: An introduction. New York: St. Martins.

\section{Copyrights}

Copyright for this article is retained by the author(s), with first publication rights granted to the journal.

This is an open-access article distributed under the terms and conditions of the Creative Commons Attribution license (http://creativecommons.org/licenses/by/4.0/). 